\title{
22. PALEOMAGNETISM OF GABBROIC ROCKS AND PERIDOTITES FROM SITES 894 AND 895, LEG 147, HESS DEEP: RESULTS OF HALF-CORE AND WHOLE-CORE MEASUREMENTS ${ }^{1}$
}

\author{
Eiichi Kikawa, ${ }^{2}$ Paul R. Kelso, ${ }^{3}$ Janet E. Pariso, ${ }^{4}$ and Carl Richter ${ }^{5}$
}

\begin{abstract}
During Leg 147, in addition to measurements made on minicore samples, remanent magnetization of the archive half of the split core was measured using the cryogenic magnetometer. Magnetic susceptibility was measured on whole cores using the multisensor track aboard the JOIDES Resolution. High intensities of natural remanent magnetization were observed in the gabbroic rocks and the peridotites, which suggests that the lower oceanic crust to upper mantle section contributes significantly to the marine magnetic anomalies. Many of the measurements made on both the gabbroic rocks and the peridotites indicated the presence of secondary magnetizations probably acquired during drilling. The observed secondary magnetization is of mixed polarities regardless of the lithology. Similar values for the average stable inclinations obtained from both sites, which are significantly steeper than the expected value of zero, suggest that both sites experienced a similar post-cooling tectonic rotation with respect to the horizontal axis.
\end{abstract}

\section{INTRODUCTION}

The location of the magnetized rocks in the oceanic crust that are responsible for seafloor spreading magnetic anomalies has been a long-standing problem in geophysics. Magnetic inversion studies indicated that the upper oceanic extrusive layer (layer $2 \mathrm{~A}, 0.5 \mathrm{~km}$ thick) was the only magnetic layer and that it was not necessary to postulate any contribution from the sheeted dike complex (layer 2B, $1.0 \mathrm{~km}$ ) or from the intrusive layer (layer 3,4.5 km; Talwani et al., 1971, Atwater and Mudie, 1973).

Direct measurements of the magnetic properties of the oceanic rocks from the seafloor, however, have shown that (1) the magnetization of layer $2 \mathrm{~A}$ is insufficient to give the required size of observed magnetic anomalies and (2) some contribution from lower intrusive rocks is necessary (Harrison, 1987). The magnetic data obtained from oceanic intrusive rocks have been equivocal, in part because studies were conducted on unoriented dredged and ophiolite samples and on intermittent cores from the Deep Sea Drilling Program (DSDP)/ Ocean Drilling Program (ODP). Recent results obtained from the continuous Hole $735 \mathrm{~B}$ gabbroic section, which had a high recovery rate of $87 \%$, showed a reasonably high intensity of $1.5 \mathrm{~A} / \mathrm{m}$ (e.g., Kikawa and Ozawa, 1992). Samples from Hole 670A indicated an average magnetization of $2.5 \mathrm{~A} / \mathrm{m}$, which suggests the upper mantle peridotites have a strong enough magnetization to contribute to marine magnetic anomalies (Hamano et al., 1990). Because both Holes $735 \mathrm{~B}$ and $670 \mathrm{~A}$ are located at the slow-spreading ridges, we have sought a direct sampling at the fast-spreading ridge.

In this paper we present a new data set for the lower oceanic intrusive rocks and the upper mantle peridotites by providing results of

'Mével, C., Gillis, K.M., Allan, J.F., and Meyer, P.S. (Eds.), 1996. Proc. ODP, Sci. Results, 147: College Station, TX (Ocean Drilling Program).

${ }^{2}$ Marine Geology Department, Geological Survey of Japan, 1-1-3 Higashi, Tsukuba, Ibaraki 305, Japan. (Current address: Global Environmental Laboratory, University of Toyama, 3190 Gofuku, Toyama 930, Japan.) U.S.A

Institute for Rock Magnetism, University of Minnesota, Minneapolis, MN 55455 ,

${ }^{4}$ School of Oceanography, University of Washington, Seattle, WA 98195 , U.S.A.

${ }^{5}$ Ocean Drilling Program, 1000 Discovery Drive, Texas A\&M University Research Park. College Station. TX 77845, U.S.A. half/whole cores recovered at Sites 894 and 895, Hess Deep, a fastspreading mid-ocean ridge located at approximately $101^{\circ} \mathrm{W}, 2^{\circ} \mathrm{N}$. A sequence of high-level gabbroic rocks was recovered at Site 894. At Site 895 , located $9 \mathrm{~km}$ southeast of Site 894 , a sequence of mafic (troctolites, olivine gabbros, gabbros, and basaltic dikes) and ultramafic (dunites, harzburgites) rocks was recovered. The magnetic properties reported here are the intensity and inclination of natural remanent magnetization (NRM), the initial magnetic susceptibility, the median demagnetizing field (MDF) for NRM, and the secondary and stable inclinations.

\section{EXPERIMENTAL PROCEDURES}

A 2-G Enterprises (Model 760R) pass-through cryogenic rock magnetometer was used to measure continuous core pieces aboard the JOIDES Resolution during Leg 147. Portions of the archive half of the core that were greater than approximately $20 \mathrm{~cm}$ long were measured at 5-cm intervals. NRM measurements on Section 147. $894 \mathrm{G}-2 \mathrm{R}-2$ were made incorrectly because of an error in the gain setting of one axis of the cryogenic magnetometer. An alternating field (AF) demagnetizer (Model 2G600), capable of producing an alternating field up to $20 \mathrm{mT}$, was used on-line with the pass-through cryogenic magnetometer. Measurements of NRM were performed after demagnetization levels of $1,2,3,4,6,8,10,12$, and $15 \mathrm{mT}$. Because of the potential for overheating the coils, demagnetization was not performed at levels over $15 \mathrm{mT}$. Subsequent to demagnetization, individual components of magnetization were identified for each portion measured using a least-squares fitting routine applied to each component of magnetization identified on an orthogonal (Zijderveld) vector diagram (Zijderveld, 1967). MDF, a peak alternating field at which half of the original remanence is demagnetized, was determined from demagnetization curves when NRMs were decreased below half by an applied field of $15 \mathrm{mT}$. As discussed later, many of the stepwise demagnetizations up to $15 \mathrm{mT}$ were successful in identifying the secondary and stable components, and also the MDF.

Whole-core magnetic susceptibility $(k)$ was measured at $2-\mathrm{cm}$ intervals on sections of the core whose length is greater than about 15 $\mathrm{cm}$ using a Bartington Instruments' susceptibility meter (Model MS1). 


\section{RESULTS}

\section{Site 894}

Holes $894 \mathrm{~F}$ and $894 \mathrm{G}$ provided the most significant recovery of igneous rocks from Site 894. Hole 894F, however, yielded no piece longer than approximately $20 \mathrm{~cm}$ available for half-core measurements. The igneous lithologies recovered in Hole $894 \mathrm{G}$ are gabbros and olivine gabbros in the upper part (above $45 \mathrm{mbsf}$ ) and gabbronorites and olivine gabbronorites in the lower part downhole. The grade of metamorphism and alteration observed for the samples is highly variable. For further details on lithologies, the reader is referred to Gillis and Mével (this volume).

\section{NRM Intensity and Inclination}

NRM intensities observed here are summarized in Figure 1A and 1B. Results of NRM measurements made on half cores (124 total) indicated a mean NRM intensity of $1.6 \mathrm{~A} / \mathrm{m}$, which is similar to that of minicore samples $(2.0 \mathrm{~A} / \mathrm{m})$. The range in NRM intensities of half cores $(0.14$ to $4.93 \mathrm{~A} / \mathrm{m})$ is, however, smaller than that of minicores $(0.03$ to $7.2 \mathrm{~A} / \mathrm{m})$. This is probably because the half-core measurements average a larger volume of rock than do the minicores. Therefore, we think that the half-core measurements may provide a better estimate of the average magnetization of the drilled section than do the minicores, but minicores provide a better estimate of real range of magnetization. The calculated mean value is similar to that of Hole 735B gabbros (1.5 A/m: Kikawa and Ozawa, 1992). Here we would simply note the importance that gabbros drilled at both slow- and fast-spreading ridges show a reasonably high NRM intensity contribution to the marine magnetic anomalies.

Figure IC represents a plot of NRM inclination vs. sub-bottom depth in Hole $894 \mathrm{G}$. All but one show positive inclination. The mean value is $43.3^{\circ}\left( \pm 13.7^{\circ}\right)$. It seems that olivine gabbronorites near 80 mbsf have higher inclinations than others. Paleomagnetic implications are discussed later.

\section{Magnetic Susceptibility}

Values for magnetic susceptibility $(k)$ for whole cores from Hole $894 \mathrm{G}$ are plotted vs. depth in Figure $2 \mathrm{~A}$. The susceptibility values vary from 0.00148 to 0.0722 , and have a mean of 0.016 (Fig. 2B). However, most of the values lie between 0.005 and 0.035 , which is consistent with previous studies (e.g., Fox and Opdyke, 1973; Kikawa and Pariso, 1991). Results of minicore samples show a similar range and identical mean values (see Pariso et al., this volume).

Like NRM intensities, the high sample density of the whole-core susceptibility measurements gave continuous observation of downhole variations in magnetic susceptibility (Fig. 2B). Comparison of Figures $1 \mathrm{~A}$ and $2 \mathrm{~A}$ indicates that the variation in magnetic susceptibility with depth correlates with NRM intensities, which suggests that NRM intensities are largely dependent upon the concentration of magnetic minerals.

Unlike in minicore samples, the Koenigsberger ratios were not calculated for half/whole cores because the portions measured are different in the NRM and susceptibility measurements.

\section{Alternating Field Demagnetizations}

Stepwise alternating field demagnetizations up to $15 \mathrm{mT}$ were performed on the archive half of the whole core. Like minicore samples in which remanences are mainly carried by single-domain magnetites (average MDF is $28.6 \mathrm{mT}$; see Pariso et al., this volume), the half cores were also resistant to AF demagnetization. For 90 measurements out of 124 , more than $50 \%$ of the magnetization remained after the 15-mT step (Fig. 3A, B). For the remaining 34 measurements, at $15-\mathrm{mT}$ step the remanence was decreased below $50 \%$, allowing MDF determinations (average $=10.4 \mathrm{mT}$, Fig. 3C).
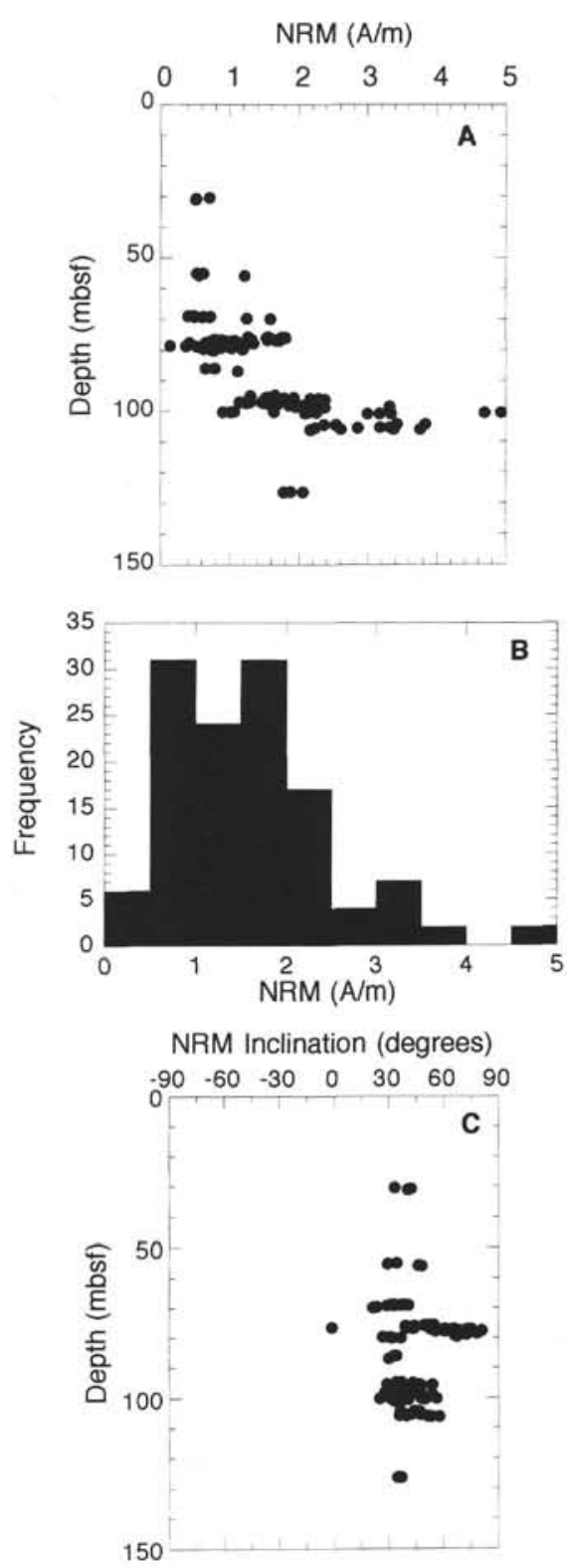

Figure 1. A. Plot of the intensity of NRM vs. depth in Hole 894G for halfcore samples. B. Histogram of the intensity of NRM for half cores from Hole 894G. C. Inclination values of NRM are plotted vs. depth for Hole 894G and show that all measurements but one are positive. In addition, olivine gabbronorites near $80 \mathrm{mbsf}$ exhibit steeper inclinations than do others.

Individual components of magnetization were determined for each measurement using a least-square fit of each component of magnetization identified on an orthogonal plot (Zijderveld, 1967). Eighty-six measurements indicated the presence of a secondary components. In most cases, this secondary magnetization is soft (removed by the $4-\mathrm{mT}$ step, Fig. 3) and is characterized by having both positive and negative polarities as well as steep inclinations (Fig. 4). Seven measurements further indicated another soft component (removed by the 8-mT step) which has positive and steep (average $=55.0^{\circ} \pm 22.2^{\circ}$ ) inclinations. Because the axial geocentric geomagnetic field inclination at Site $894\left(2^{\circ} \mathrm{N}\right)$ is very close to $0^{\circ}$, it is unlikely that the secondary component was acquired parallel to the ambient geomagnetic field at the site. Previous studies of DSDP/ODP drill cores have shown that soft and steep components of magnetization are probably remanent magnetizations acquired during drilling (e.g., Lowrie and 

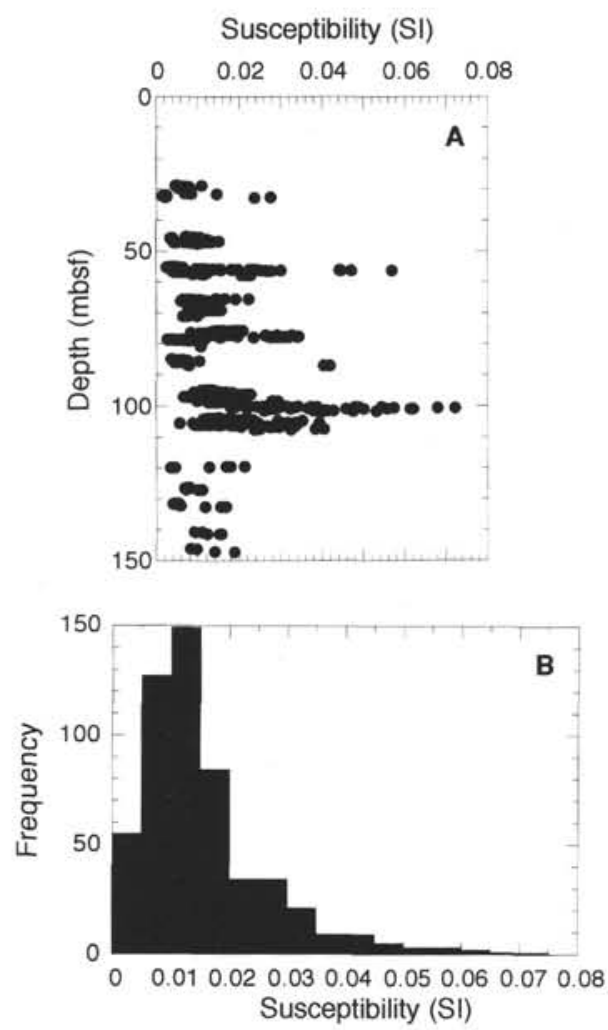

Figure 2. A. Plot of magnetic susceptibility vs. depth in Hole $894 \mathrm{G}$ for whole-core samples. B. Histogram of magnetic susceptibility for whole cores from Hole $894 \mathrm{G}$.

Kent, 1978; Kikawa and Pariso, 1991). The observed secondary magnetization which generally had soft and steep components is probably drilling-induced remanent magnetization.

\section{Direction of Remanent Magnetization}

As mentioned above, for about $70 \%$ of the measurements, more than $50 \%$ of the NRM intensity remained after the $15-\mathrm{mT}$ step. Therefore, the alternating fields used were not completely enough to isolate the stable magnetizations of the half cores. However, for the cases shown in Figure 3, the magnetization directions estimated from a least-squares fitting from steps 6 to $15 \mathrm{mT}$ would probably be close to the stable remanence directions, though the magnetic vector behavior after $15 \mathrm{mT}$ was unknown. When those cases were taken as "successful" in estimating a stable component, together with the fact that minicore samples generally did not show large directional changes during the stepwise alternating field demagnetization up to 100 $\mathrm{mT}$, a total of 126 "stable directions" were then obtained for the half cores recovered from Hole $894 \mathrm{G}$ (Fig. 5). Figure 5 shows that the stable inclinations are steeper below 70 mbsf: most of the stable inclinations below $70 \mathrm{mbsf}$ are more than $40^{\circ}$, whereas many of those above this depth are less than $40^{\circ}$. This observation is consistent with that for minicore samples (see Pariso et al., this volume). The average inclination is $51.2^{\circ}\left( \pm 13.9^{\circ}\right)$, which is significantly steeper than the expected value for Site 894 (very close to $0^{\circ}$ ). Possible causes of this steeper inclination are paleosecular variation and tectonic rotation. In this case, tectonic rotation is very likely because only up to $13^{\circ}$ of angular dispersion can be expected in inclination values during the past $5 \mathrm{Ma}$ for Site $894\left(2^{\circ} \mathrm{N}\right)$ due to secular variation (McFadden and Merrill, 1975).
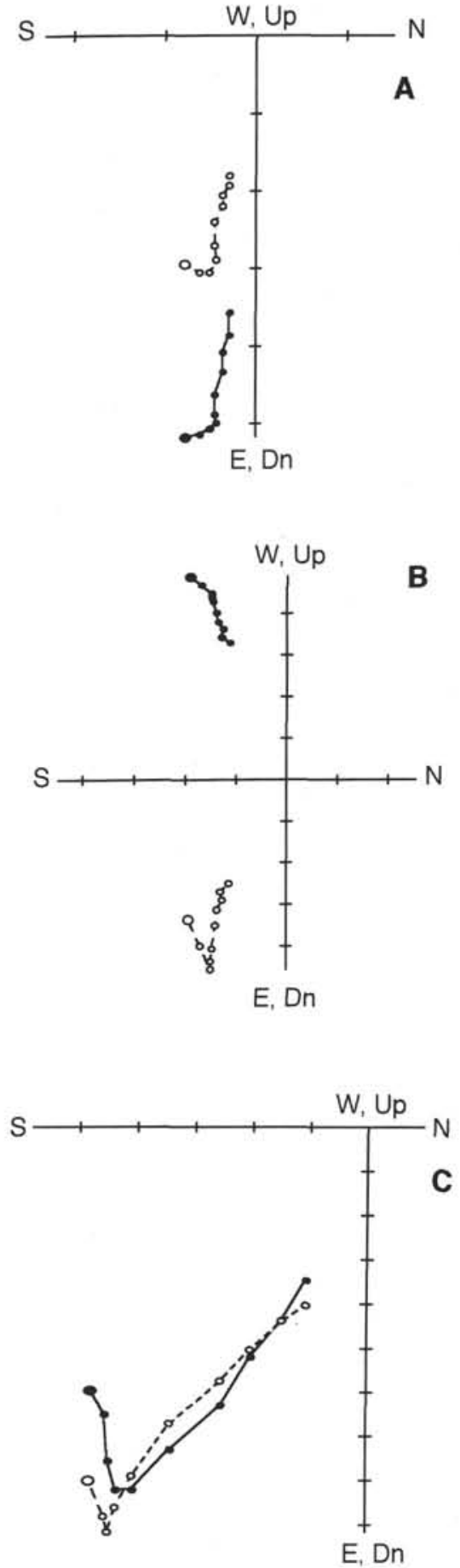

Figure 3. Zijderveld plots for three measurements. Measurements at Section 147-894G-6R-1, $50 \mathrm{~cm}$ (A), and at Section 147-894G-12R-3, $120 \mathrm{~cm}$ (B), are typical of many Hole $894 \mathrm{G}$ gabbroic rocks, indicating the presence of a secondary component that is soft (removed by $4 \mathrm{mT}$ ). For about $70 \%$ of the measurements, more than $50 \%$ of the remanent magnetization remained after the $15-\mathrm{mT}$ step (A and B). However, for the remaining $30 \%$ of the measurements the remanence was decreased below $50 \%$-for example, the measurement at Section 147-894G-6R-1, $95 \mathrm{~cm}$ (C). We feel that the stable remanence directions could be estimated from these plots, though the 15-mT step was obviously not enough to demagnetize the half cores. 


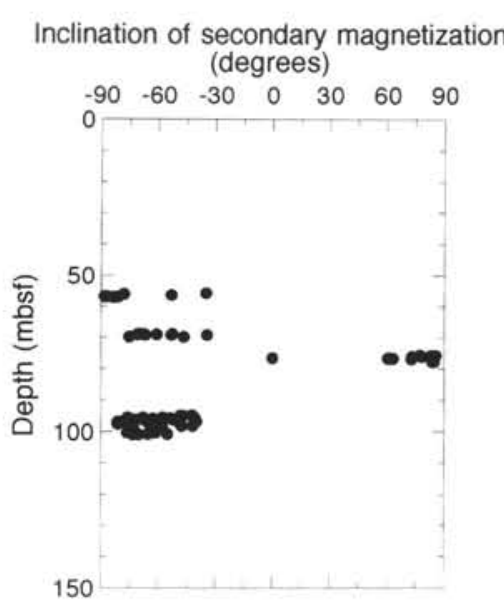

Figure 4. Inclination values of secondary components of magnetization determined from half cores are plotted vs. depth for Hole 894G. Note that the secondary components show mixed polarities with steep inclinations.

\section{Discussion}

As stated above, half-/whole-core measurements generally provide a better estimate of remanent magnetization and susceptibility in recovered sections, providing a more continuous record than do the minicore samples. The average intensity and susceptibility obtained for the half cores from the Hole $894 \mathrm{G}$ gabbroic section are $1.6 \mathrm{~A} / \mathrm{m}$ and 0.016 , respectively. The ratio of these two parameters suggests that the in situ magnetization of this crustal section is carried by remanent magnetization. These magnetic properties are similar to those obtained for Leg 118 gabbros which were from the slow-spreading Southwest Indian Ridge (Kikawa and Pariso, 1991). This fact may suggest that magnetic properties for oceanic intrusive rocks are similar between fast- and slow-spreading ridges, thus for both ridge systems oceanic intrusive rocks contribute significantly to the marine magnetic anomalies.

The half-core measurements also seemed to be successful in detecting the secondary components acquired by the cores since they are usually soft and easily removed by the $15-\mathrm{mT}$ alternating field. Similar to the Leg 118 gabbros, the half cores of gabbroic rocks from Hole $894 \mathrm{G}$ acquired the secondary magnetizations with steep inclinations. Although the acquisition mechanism is not clear, it is very likely that the secondary magnetization was acquired during drilling, since secondary magnetizations such as viscous remanent magnetization (VRM), chemical remanent magnetization (CRM), or partial thermoremanent magnetization (PTRM) should be acquired parallel to the ambient geomagnetic field at the site (nearly zero).

In contrast to remanence intensity and secondary component estimates, half-core measurements of Hole $894 \mathrm{G}$ provided poorer estimates of stable directions, as the alternating field demagnetizations were not performed at the steps over $15 \mathrm{mT}$. However, the estimated stable inclinations indicated a tendency consistent with that of minicore samples, which provide the most confident estimate of the stable remanence directions. This is in part because the remanences of Hole $894 \mathrm{G}$ gabbros have good stability against the alternating field. As mentioned above, the calculated average of stable inclinations of $51.2^{\circ}$, which is significantly steeper than the expected value close to $0^{\circ}$, was probably caused by tectonic rotation after cooling of the crustal section. This rotation was also observed for Hole 735B gabbros (Kikawa and Pariso, 1991), suggesting that crustal rotation after cooling of the oceanic intrusive section commonly occurs during the process of its emplacement to the seafloor at a mid-ocean ridge system.

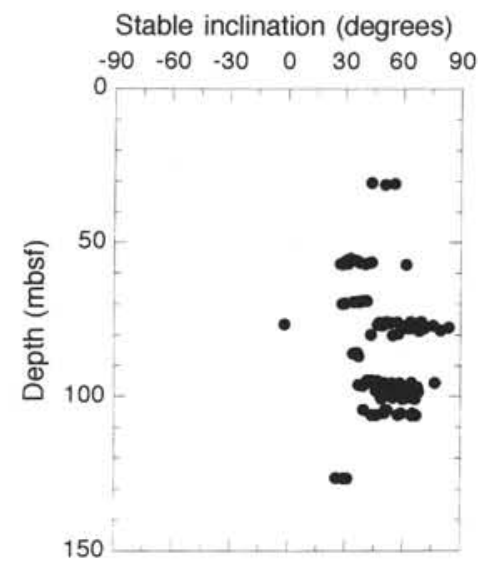

Figure 5. Stable magnetic inclination values determined from half cores are plotted vs. depth for Hole 894G. The inclination values are steeper below 70 mbsf.

\section{Site 895}

Four of the six holes drilled at this site (895A, 895B, 895C, and $895 \mathrm{~F}$ ) were cored to a maximum of $37.9 \mathrm{mbsf}$ and had poor recovery. However, Holes 895D and 895E were drilled to 93.7 and $87.6 \mathrm{mbsf}$, respectively, with relatively high recovery. Igneous lithologies sampled from Site 895 include dunite, harzburgite, gabbroic rocks, and basalt. In Hole $895 \mathrm{D}$, harzburgite is predominant over dunite and mafic rocks. The predominant lithology for Hole $895 \mathrm{E}$ is variably serpentinized and weathered dunite. For more details, see Mével and Gillis (this volume).

\section{NRM Intensity and Inclination}

NRM intensities measured from half cores vary over a range of about four orders of magnitude with an arithmetic mean of $2.5 \mathrm{~A} / \mathrm{m}$ (Fig. 6). This large variation is directly related to the differences in rock types: the average intensity for 16 measurements from gabbroic rocks is $0.007 \mathrm{~A} / \mathrm{m}$, and the mean calculated for 237 measurements from peridotites is $2.7 \mathrm{~A} / \mathrm{m}$. The average for peridotites is consistent with that of minicores $(3.0 \mathrm{~A} / \mathrm{m}$, see Kelso et al., this volume) and is similar to the previously reported mean values of $2.4-8.2 \mathrm{~A} / \mathrm{m}$ (e.g., Dunlop and Prevot, 1982; Hamano et al., 1990), which suggests that the upper mantle peridotites are magnetized strongly enough to contribute to the marine magnetic anomalies. Like minicore samples, continuous half-core measurements also show substantial differences in magnetization between harzburgites (dominant in Hole 895D) and dunites (dominant in Hole 895E): 67 measurements for harzburgites yielded an average of $1.6 \mathrm{~A} / \mathrm{m}$, and 170 measurements for dunites resulted in an average of $3.1 \mathrm{~A} / \mathrm{m}$ (Fig. 7).

NRM inclinations observed within Holes 895D and 895E are summarized in Figure 8. As evident from Figure 8, some reversals of NRM inclination were observed in the two holes. However, it seems that both holes are characterized by positive and steep inclinations $\left(>40^{\circ}\right)$. Paleomagnetic discussions are given later.

\section{Magnetic Susceptibility}

Whole-core susceptibility values are plotted vs. depth in Figure 9. Five-hundred fifty measurements from peridotites have values ranging between 0.0027 and 0.1 (Fig. 13, average $=0.036$ ), much higher than those of 37 values from gabbroic rocks (from 0.00014 to 0.0012 , with an average of 0.00039 ). The mean value and range observed for peridotites are similar to previously reported values (e.g., Fox and Opdyke, 1973; Dunlop and Prevot, 1982). As shown in Figure 9, sus- 

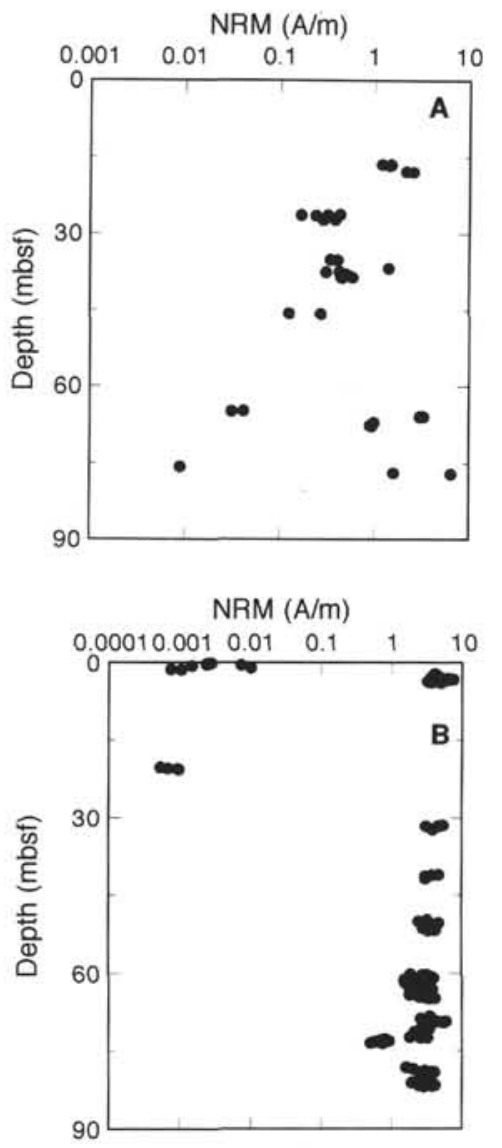

Figure 6. Plots of NRM intensity vs. depth in Holes 895D (A) and 895E (B).

ceptibility values from Hole $895 \mathrm{D}$ are somewhat lower than those of Hole $894 \mathrm{E}$, indicating that the harzburgites are relatively less magnetic than the dunites. This observation is consistent with that of NRM intensity.

The positive correlation between susceptibilities and NRM intensities for Holes $895 \mathrm{D}$ and $895 \mathrm{E}$ suggests that the remanence is a function of the concentration of magnetic minerals.

\section{Alternating Field Demagnetization}

Results of minicore samples showed that the peridotites were relatively easily demagnetized by the alternating field demagnetization: MDFs for harzburgites and dunites are 12.1 and $10.3 \mathrm{mT}$, respectively (see Kelso et al., this volume). This observation indicates that stepwise alternating field demagnetizations up to $15 \mathrm{mT}$ would be enough to detect MDFs for half cores in most cases. MDFs were determined (Figs. 10, 11) from 235 measurements (out of 237). As shown in Figure 11, the dunites seem to be generally less resistant to the alternating field demagnetization than do the harzburgites, though there is a significant overlap in their ranges of MDF. The higher stability of the harzburgites against the alternating field is evident from the MDF average values: $10.7 \mathrm{mT}$ for the harzburgites and $9.4 \mathrm{mT}$ for the dunites. The mean MDF value of $9.8 \mathrm{mT}$ for peridotites is less than half of the mean MDF of $28.6 \mathrm{mT}$ of gabbroic rocks at Hole $894 \mathrm{G}$. The lower MDF for the peridotites suggests that their magnetic stability is substantially less than that of the gabbroic rocks from Hole 894G.

Individual magnetization components were determined from a least-squares approximation using Zijderveld diagrams obtained for progressive demagnetization data (Zijderveld, 1967). One hundred
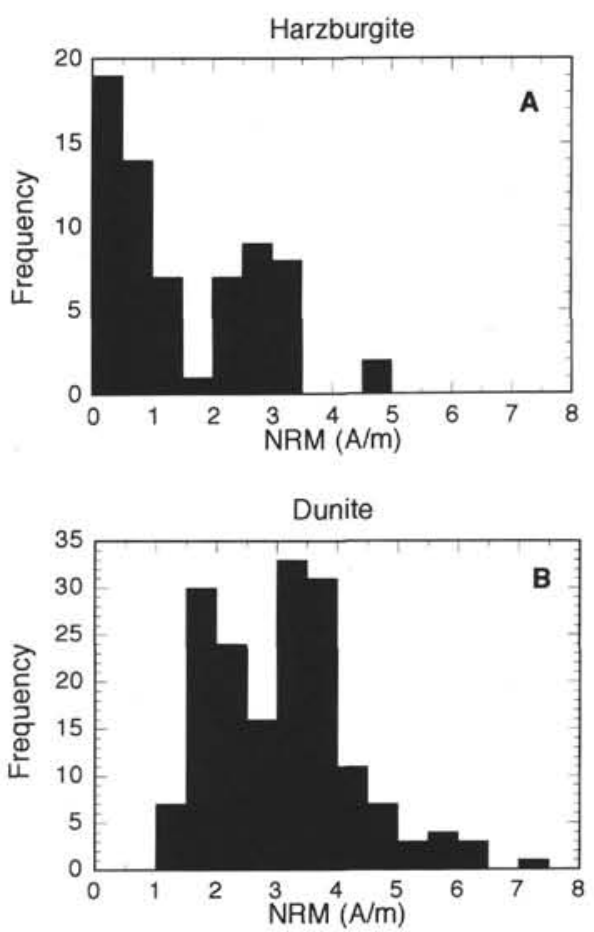

Figure 7. Histograms of NRM intensity. Harzburgites (A) are less magnetic than dunites (B).

nineteen measurements indicated a presence of the secondary component removed by about $6 \mathrm{mT}$ of alternating field (Fig. 10B, C). This secondary component is similar to that observed for Hole 894G gabbroic rocks, being characterized by having positive and negative polarities with steep inclinations (Fig. 12). Thirty-four measurements further showed the existence of another secondary component which is usually removed by $10 \mathrm{mT}$ of alternating field (Fig. 10C). This secondary component is shown in Figure 12, where the majority of measurements indicate positive and steep inclinations, similar to those observed for the gabbroic rocks from Hole 894G. The secondary magnetizations observed were unlikely acquired parallel to the ambient geomagnetic field at Site 895, since the predicted magnetic inclination at the site $\left(2^{\circ} \mathrm{N}\right)$ is very close to $0^{\circ}$. The nature of the secondary component is again similar to that of drilling-induced remanent magnetization (soft and steep component; e.g., Lowrie and Kent, 1978; Kikawa and Pariso, 1991), which suggests that it was probably acquired during drilling.

\section{Direction of Remanent Magnetization}

In contrast with measurements from gabbroic rocks from Hole $894 \mathrm{G}$, most of the half-core measurements indicated a decrease in remanent magnetization below about $30 \%$ of the NRM intensity, which suggests it is possible to make a more confident estimate for the stable component than for the half cores from Hole 894G, though the magnetic behavior at the steps over $15 \mathrm{mT}$ was not examined (Fig. 10). Thus, a total of 170 stable magnetizations were estimated for the half cores from Site 895 . Figure 13 shows stable inclinations plotted vs. depth. In contrast to NRM inclinations and the stable inclinations obtained for the minicore samples that indicated some geomagnetic field reversals within the holes (see Kelso et al., this volume), stable inclinations estimated for the half cores are characterized by positive and steep inclinations. The average inclination calculated for Hole $895 \mathrm{D}$, excluding the two negative inclinations (Fig. 13A), was $45.1^{\circ}$ $\left( \pm 10.7^{\circ}\right)$, and the mean stable inclination obtained from Hole $895 \mathrm{E}$, leaving the two negative inclinations out of the calculation (Fig. 
NRM inclination (degrees)

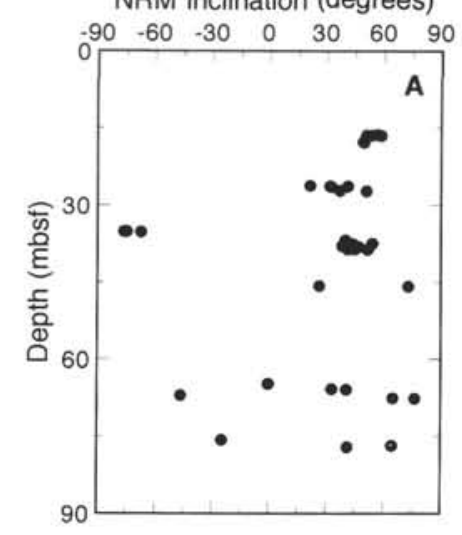

NRM inclination (degrees)

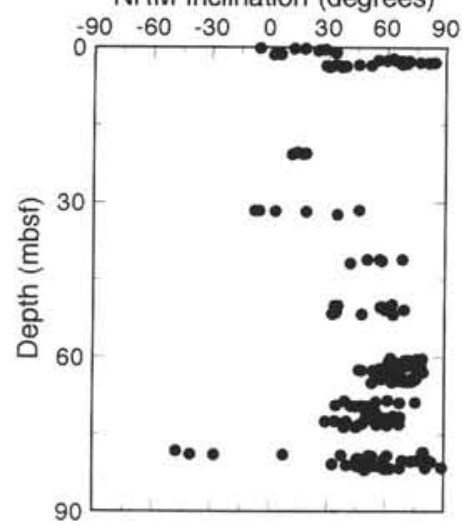

Figure 8. NRM inclination values for Holes 895D (A) and 895E (B). Several geomagnetic reversals are observed in the two holes. Both holes, however, are characterized by positive and steep inclinations.

$13 \mathrm{~B})$, was $62.0^{\circ}\left( \pm 13.6^{\circ}\right)$. The average stable inclination calculated for Site 895 is $55.7^{\circ}\left( \pm 22.7^{\circ}\right)$, which is slightly steeper but similar to that of Hole $894 \mathrm{G}\left(51.2^{\circ} \pm 13.9^{\circ}\right)$. As mentioned above, the expected magnetic inclination for Site 895 is near zero. Half cores from both Sites 894 and 895 consequently have stable inclination values that are substantially steeper than the expected values. It is thus probable that the two crustal sections underwent significant tectonic rotation about a horizontal axis subsequent to acquisition of remanent magnetization.

\section{Discussion}

The ratio of the average NRM intensity $(2.7 \mathrm{~A} / \mathrm{m})$ and magnetic susceptibility $(0.036)$ obtained by half-/whole-core measurements of peridotites suggests that the in situ magnetization of the upper mantle crustal section at Site 895 is dominated by remanent magnetization, rather than instantaneous magnetization induced by the present geomagnetic field. This observation is consistent with previous studies (e.g., Dunlop and Prevot, 1982; Hamano et al., 1990), though $\mathrm{Ha}-$ mano et al. (1990) stated the importance of the induced magnetization of the peridotites. As mentioned above, the average NRM intensity and other magnetic properties are similar to those reported for previous studies carried out at slow-spreading ridges, (e.g., Dunlop and Prevot, 1982; Hamano et al., 1990), which suggests that magnetic nature of the upper mantle peridotites formed at both slow- and fast-spreading ridges is not so different. The average NRM intensity of $2.7 \mathrm{~A} / \mathrm{m}$ is reasonably high to consider the upper mantle peridotites at Site 895 as a source of the marine magnetic anomalies.
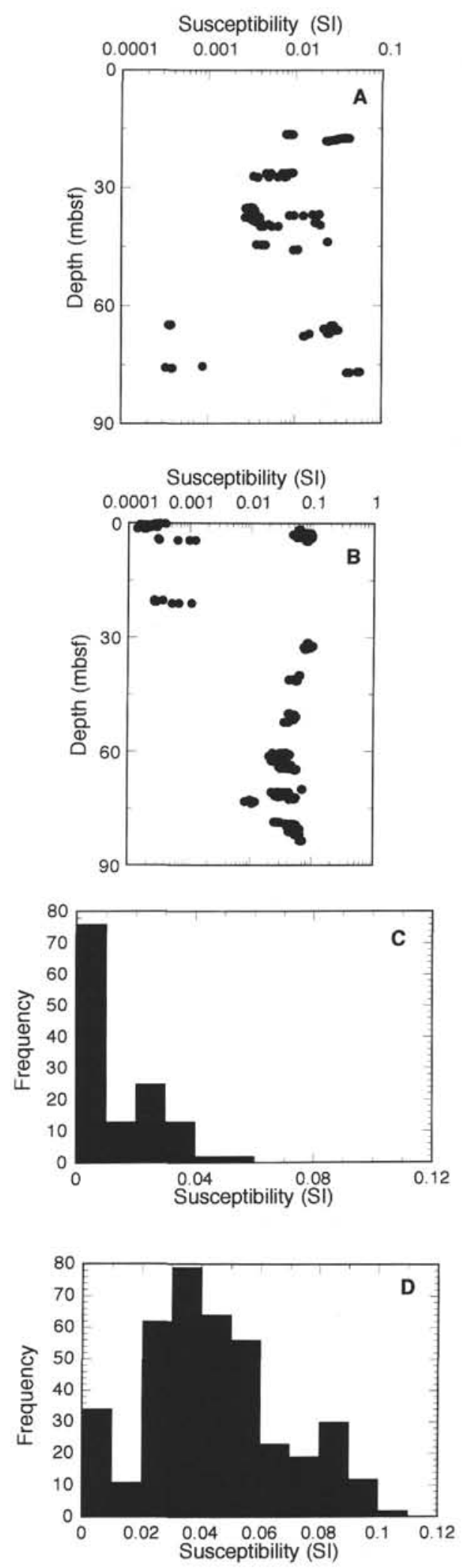

Figure 9. Plots of magnetic susceptibility vs. depth in Holes 895D (A) and $895 \mathrm{E}$ (B), and histograms of magnetic susceptibility of whole cores from Hole 895D (C) and from Hole 895E (D). 

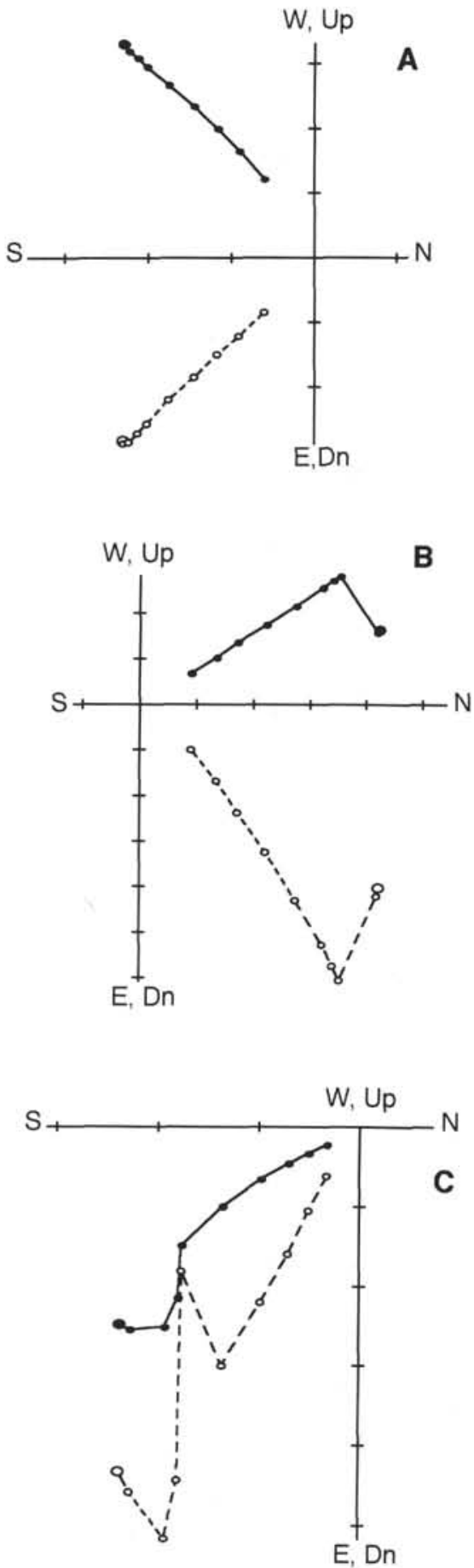

Figure 10. Zijderveld plots of alternating field demagnetization data. A. Typical example of stable remanence data (measurement at Section 147-895E$5 \mathrm{R}-1,115 \mathrm{~cm}$ ). The Zijderveld diagram shows no change in magnetic direction during magnetization. B. Typical example of data including unstable secondary component (measurement at Section 147-895E-4R-2, $90 \mathrm{~cm}$ ). The secondary component which has steep inclination was demagnetized during lower alternating field demagnetization steps (in most cases, up to $6 \mathrm{mT}$ ), followed by the appearance of a stable component in the higher demagnetization steps. C. Typical example of data including three components (measurement at Section 147-895E-1R-3, $60 \mathrm{~cm}$ ). The softer secondary magnetization with steep negative inclination was demagnetized (usually by $6-\mathrm{mT}$ step), and then the harder secondary magnetization was detected (up to $10 \mathrm{mT}$ ), followed by the appearance of a stable component in the higher demagnetization steps.
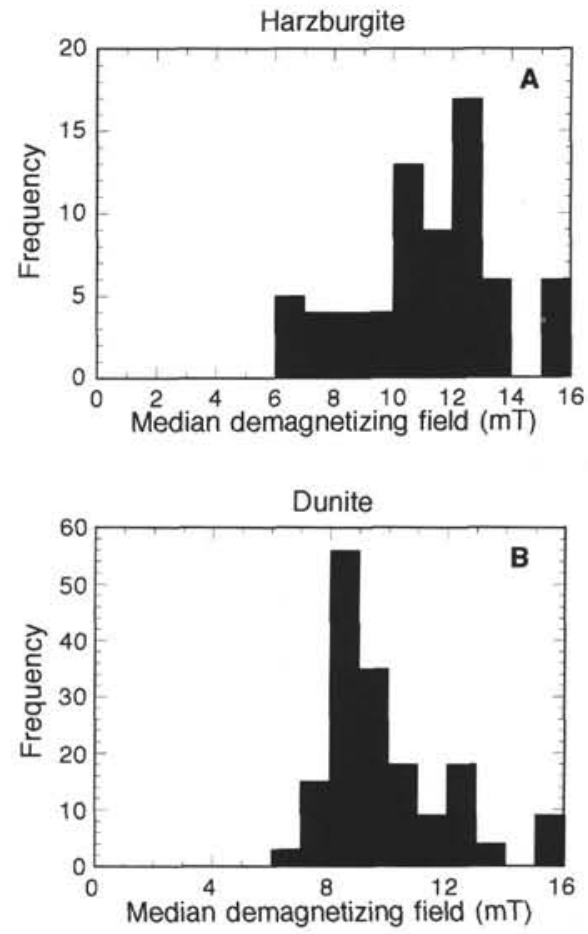

Figure 11. Histograms of the median destructive field (MDF) for different lithologies. A. Harzburgite. B. Dunites, which seem to be less resistant to the alternating field.

Because of relatively less stability against the alternating field demagnetization, stepwise demagnetizations up to $15 \mathrm{mT}$ were successful in detecting MDFs and secondary/stable magnetizations of the peridotites. The MDF values of the dunites (average $=9.4 \mathrm{mT}$ ) lower than those of the harzburgites (average $=10.7 \mathrm{mT}$ ), suggest that the dunites contain a larger size of magnetite. The stepwise alternating field demagnetization up to $15 \mathrm{mT}$ made for gabbroic rocks from Hole $894 \mathrm{G}$ was not enough to detect MDFs, indicating that gabbroic rocks from Hole $894 \mathrm{G}$ probably have smaller grain-size magnetite than do the peridotites. This is consistent with the minicore samples and previous studies (Kelso et al., this volume; e.g., Dunlop and Prevot, 1982; Hamano et al., 1990; Kikawa and Ozawa, 1992).

The secondary magnetizations observed for the peridotites were considered to be acquired during drilling because such soft magnetizations with steep inclinations were very difficult to acquire at Site 895 , except for the drilling-induced mechanism (e.g., Lowrie and Kent, 1978; Kikawa and Pariso, 1991). However, in contrast to some of the previous studies (e.g., Kikawa and Pariso, 1991), the secondary magnetizations observed for both the gabbroic rocks and the peridotites at Sites 894 and 895 indicated mixed polarities with no correlation to the lithology.

Similar values for the average inclinations $\left(51.2^{\circ}\right.$ for Site 894 and $55.7^{\circ}$ for Site 895 ) suggest that both sections underwent a similar amount of tectonic rotation. This further suggests, together with the previous study by Kikawa and Pariso (1991) that postulated tectonic rotation of the lower oceanic crustal section after cooling, that the lower oceanic and upper mantle section generally experiences tectonic rotation during the process of its emplacement to the seafloor.

\section{CONCLUSIONS}

1. The magnetization values obtained from 124 measurements made on half cores of gabbroic rocks from Hole $894 \mathrm{G}$ have an arithmetic mean of $1.6 \mathrm{~A} / \mathrm{m}$, which is similar to that of minicore samples $(2.0 \mathrm{~A} / \mathrm{m})$. The mean value calculated for 237 half-core measure- 
Figure 12. Inclination values of secondary components of magnetization determined from half cores are plotted vs. depth for Holes 895D (A) and 895E (B). These secondary components were generally demagnetized by $6 \mathrm{mT}$. Note that the secondary components show mixed polarities with steep inclinations. Inclination values of harder secondary components of magnetization observed are plotted vs. depth for Holes 895D (C) and $895 \mathrm{E}$ (D). These secondary components were harder than those shown in (A) and (B) and generally demagnetized by $10 \mathrm{mT}$. Note that these secondary magnetizations are characterized by positive polarities with steep inclinations.

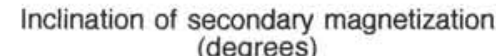
(degrees)

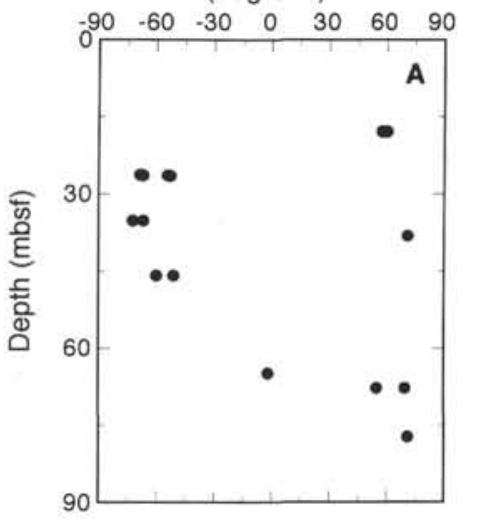

Inclination of harder secondary magnetization (degrees)

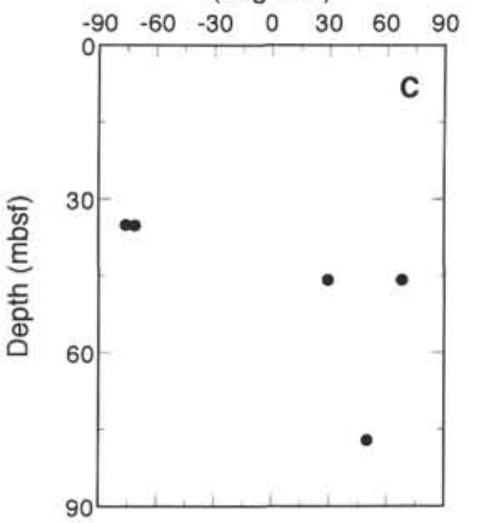

Inclination of secondary magnetization (degrees)

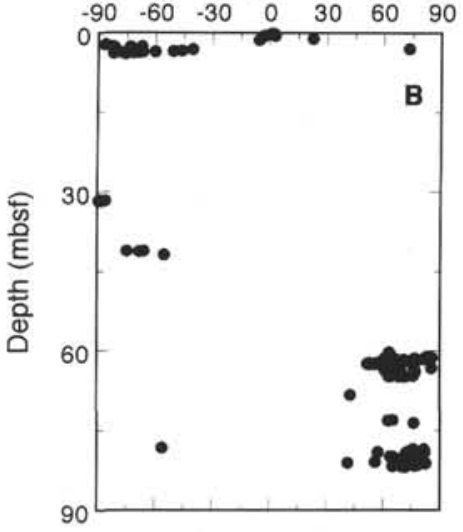

Inclination of harder secondary component (degrees)

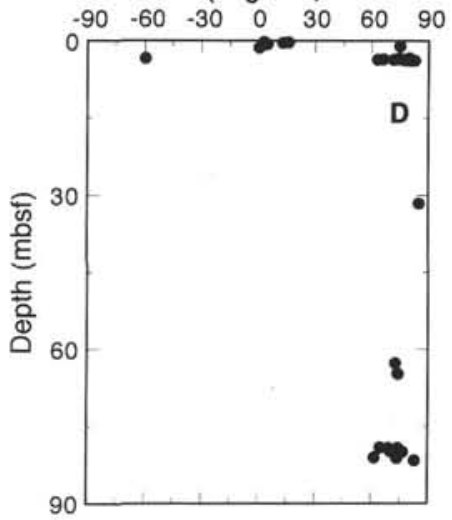

ments of peridotites from Site 895 is $2.7 \mathrm{~A} / \mathrm{m}$. The average values suggest that significant contribution to the marine magnetic anomalies come from the lower oceanic crust and upper mantle.

2. Many of measurements made on both the gabbroic rocks and the peridotites indicated the presence of a secondary magnetization probably acquired during drilling. The observed secondary magnetization reveals mixed polarities regardless of the lithology.

3. Similar values for the average stable inclinations $\left(51.2^{\circ}\right.$ for Site 894 and $55.7^{\circ}$ for Site 895 ) suggest that both sites experienced a similar amount of post-cooling tectonic rotation.

\section{ACKNOWLEDGMENTS}

We thank the Leg 147 Scientific Party, technical staff, crew members, and staff of the Ocean Drilling Program in College Station for their cooperation, and two anonymous referees for their comments which improved the manuscript. The senior author expresses his special thanks to the Japan ODP committee (chaired by A. Taira) for their help.

\section{REFERENCES}

Atwater, T.M., and Mudie, J.D., 1973. Detailed near-bottom geophysical study of the Gorda Rise. J. Geophys. Res., 78:8665-8586.

Dunlop, D.J., and Prevot, M., 1982. Magnetic properties and opaque mineralogy of drilled submarine intrusive rocks. Geophys. J. R. Astron. Soc., 69:763-802.
Fox, P.J., and Opdyke, N.D., 1973. Geology of the oceanic crust: magnetic properties of oceanic rocks. J. Geophys. Res., 78:5139-5154.

Hamano, Y., Bina, M.M., and Krammer, K., 1990. Paleomagnetism of the serpentinized peridotite from ODP Hole 670A. In Detrick, R., Honnorez, J., Bryan, W.B., Juteau, T., et al., Proc. ODP, Sci. Results, 106/109: College Station, TX (Ocean Drilling Program), 257-262.

Harrison, C.G.A., 1987. Marine magnetic anomalies-the origin of the stripes. Annu. Rev. Earth Planet. Sci., 15:505-543.

Kikawa, E., and Ozawa, K., 1992. Contribution of oceanic gabbros to seafloor spreading magnetic anomalies. Science, 258:796-799.

Kikawa, E., and Pariso, J.E., 1991. Magnetic properties of gabbros from Hole 735B, Southwest Indian Ridge. In Von Herzen, R.P., Robinson, P.T., et al., Proc. ODP, Sci. Results, 118: College Station, TX (Ocean Drilling Program), 285-307.

Lowrie, W., and Kent, D.V., 1978. Characteristics of VRM in ocean basalts, J. Geophys., 44:297-315.

McFadden, P.L., and Merrill, R.T., 1975. Geomagnetic secular variation over the past 5 m.y. Rev. Geophys. Space Phys., 13:687-708.

Talwani, M., Windisch, C., and Langseth, M., 1971. Reykjanes ridge crest: a detailed geophysical study. J. Geophys. Res., 76:473-517.

Zijderveld, J.D.A., 1967. AC demagnetization of rocks: analysis of results. In Collinson, D.W., Creer, K.M., and Runcorn, S.K. (Eds.), Methods in Palaeomagnetism: New York (Elsevier), 254-286.

Date of initial receipt: 5 August 1994

Date of acceptance: 10 February 1995

Ms 147SR-024 

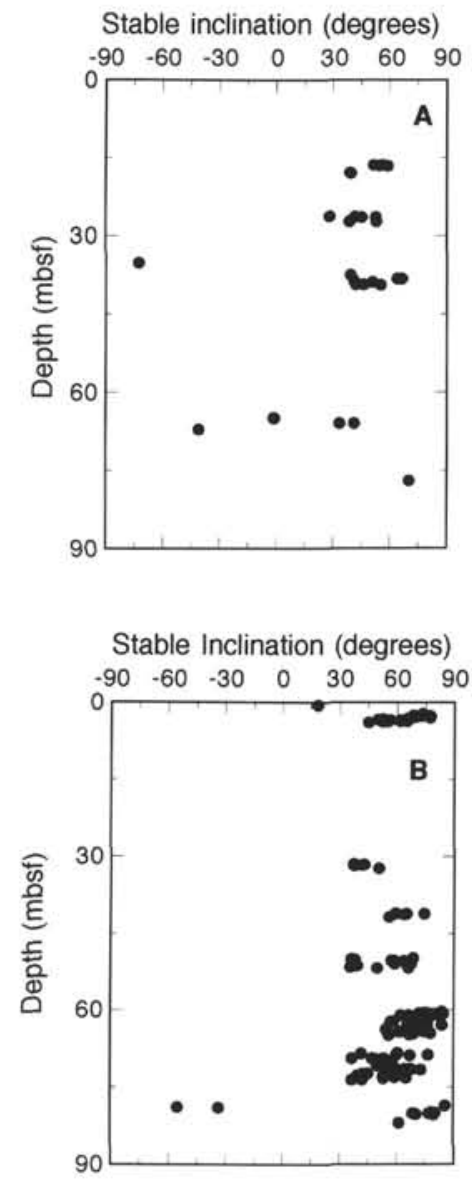

Figure 13. Stable inclination values are plotted vs. depth for Holes 895D (A) and 895E (B). The sections of the two holes seem to be uniformly magnetized in the positive polarities with steep inclinations, though two negative inclinations were observed for each hole. 